\title{
Teacher job induction and professional development in federal Nepal
}

\author{
Min Bdr. Shahi \\ PhD scholar, Tribhuvan University, Nepal \\ DOI: 10.29322/IJSRP.10.11.2020.p10766 \\ http://dx.doi.org/10.29322/IJSRP.10.11.2020.p10766
}

\begin{abstract}
The ideas about this research came because of new governing system of three tiers in Nepal. It is a mega jump from unitary government to three tiers federal government system so that teachers' job induction and professional development are challenging components to manage properly. To find the appropriate role taker and the proper execution plan is main objective of this research. McKinsey 7S management theoretical perspective was applied as a theoretical base and it was focused on staff and sharing culture. This research followed interviews and document study. Qualitative method followed in this research to cover the required data. Finally, research concluded that job induction is not followed in Nepal even it is an essential component for motivating teachers towards the profession and to keep them aware about their future results. Similarly, professional development like; training, exposure visits, workshops, observations and monitoring by supervisors and experts are tough activities to achieve the results. These activities are under the province as well as local government work better.
\end{abstract}

Index Terms- Teacher - job induction - professional development - federal Nepal - stakeholders

\section{INTRODUCTION}

$\mathrm{I}$ last century, Nepal run under Rana regime for 104 years (Sharma 1990), panchayat system under active kingship (Tamang 2000) and multiparty system under ceremonial kingship (Acharya 2006). The governing system now is federal republican system in place from the year 2015 formally. The formal education system in Nepal started during the rana regime and it continued by the following governments so that the democratization and decentralization of professional development of teachers is still less effective in place (MoEST, 2017). The central controlled unitary government showed its limited access to the teachers working in the rural and remote areas. Since teacher management was a difficult task at that time and it was not implementing job induction in a formal way as it was following by other civil service holders. Similarly, professional development of teachers was run from the central government with its regional training centers and the monitoring and execution role was appointed to the district education offices. In center, National Center for Educational Development (NCED) was established in 1993 to run the professional development activities for teaches and Department of Education was executive authority of teachers. Sometimes gaps and overlaps between these organizations reduced the effectiveness of professional development and its' materialization
(NCED, 2017). Government established Teacher Service Commission (TSC) in 2001 for the professional selection process of teachers.

Parajuli and Thapa have explored that there are several issues about teacher management like; teacher motivation, uneven distribution of teachers, various categories of teachers, poor implementation of training skills in the classroom, nepotism, favoritism and unnecessary influences in teacher recruitment and transfer (ADB, 2013). Similarly, Panta, Khanal, Phyak, Luitel et. al. also explored job induction is an another lacking component in teacher management (MoEST, 2018). Singapore government is following V3SK model of teachers' professional development (Soh 2014). Here, Teacher's values, students' values, parent's values, skills and knowledge are equally focused about teacher quality. Teacher's professional development in Brazil is another countable progress and focus to develop the teachers (Faubert 2009).

\section{RESEARCH OBJECTIVES}

- To find out the policy provision about job induction and professional development of teachers.

- To identify the key stakeholders' experiences and perspectives about job induction and professional development of teachers.

\section{RESEARCH METHODOLOGY}

Research was structured in a qualitative method where document study and interviews were conducted. I followed the ideas of (Patton 1990) about the qualitative method to increase the validity and reliability of findings. Here, qualitative data covered the emotions, experiences and feelings of respondents. Interview and focus group discussion was focused on Kathmandu and Rautahat districts because these two districts represent the different community and administrative situation. I had tried to cover more stakeholders like; head teachers, teachers, committee members, parents, political figures, journalists, development partners and students also. Obviously the government officials were part of this research.

\section{DATA COLLECTION, ANALYSIS AND INTERPRETATION}

Data collection was followed both primary and secondary sources that focus group and interview informants shared their 
primary ideas and the documents gave the secondary data to complete the research. Following ideas of (Hox and Boeije 2005), primary data have repetitions, confusions, jargon words and agreements disagreements at the same point. Since the data analysis required filtration first and coding for the analysis. Data analysis was the main component to be sincere to follow the right data in the right group. Also, to follow the data similar found in the document study and from the informants.

Data interpretation was sincerely observed that the original ideas of informants to be presented accordingly. Also, tracking the field data to research objective was sincere part in the research. The quantitative and qualitative data were gathered parallel and then explained for the further conclusions.

\section{RESEARCH LIMITATIONS}

This part of research limited on mixed method, only two components of teacher management, and purposive selection of research area and informants. All of these because of following the right area and person. The random selection may reach to the normal person who cannot answer the technical questions. The time constraint of the head teachers was another limitation that I set off time because they found very busy and distracted during the school time.

\section{ETHICAL CONSIDERATION}

Research ethics were in priority and highly considered with prior consensus the informants, and institution. Also, early clarification on objectives of research so that informants have no more confusions about use and misuse of data they share. The writers and their original content as well as ideas are addressed properly cited in this research. It is tried to mention the original ideas of informant during the analysis and interpretation also.

\section{THEORETICAL STAND POINT}

Both management and motivation theories are consulted in this research because an individual cannot be separated from the basic needs of Maslow that person cannot think beyond the basic needs at first. Since, employers need to address the basic needs of employees at first (McLeod, 2007). McLeod added that individuals' journey starts with physiological needs and grows up to self-actualization after that their horizon broaden. Herbert Spencer (1820 - 1903) developed idea of "Survival of the Fittest" on the basis of Charles Darwins' theory on origin of species. It means every individual is trying his/her best to achieve the better life with facilities and recognition.

Similarly, management principles of Max Weber (1864 1920) were essential to follow here to address the process of management. Voet, J. V. D (2013) explained in his research about organizational change that the bureaucratic organizations are able to implement the organizational changes effectively. He added that leaders having transformational behavior are able to conduct proper supervision and then the organizations run effectively (ibid). So that this research followed the bureaucratic theoretical values and ideas of human resource management where job induction and teachers' professional development follow the certain process for the better results. The process of job induction and professional development and the ways to address the organizational structure are based on this theory. The effectiveness of professional development events re analyzed based on the bureaucratic theory.

\section{RESEARCH FINDINGS}

Research concluded the different perspectives of service providers and the teacher stakeholders. The following points clary it more that the importance of job induction, it's present situation of execution and the impact of professional development of teachers.

\section{JOB INDUCTION IS AN AVOIDED COMPONENT OF TEACHER MANAGEMENT}

Education Act. (1972), Teacher Service Commission (TSC, 2001) and Education Rule/Regulation (2003) are silent about job induction program for newly recruited teachers. There is defined District Education Office (DEO) as a recruitment and monitoring responsible body so that it is understood that DEO needs to conduct the job induction program. During the interview time, District Education Development and Coordination Unit (DEDCU) head explained that they are running the job induction program, it is recognized by the system and all districts are following it.

He added,

".....the teachers selected from TSC come to DEDCU office and they take part in job induction program and then they move for the recommended schools (KII)".

Initially his answer was interesting that job induction is in place even it is not defined by the policy with importance. What they do during the job induction program run by the DEDCU was another important concern in this research. He explained about time and activities during the orientation program,

"......it is about two to three hours program where selected teachers share their experiences and then DEDCU head explains about their roles, responsibilities, DO's and DON'T in the profession (KII)."

It looks like a short orientation program for new comers and not exactly job induction because the program is not detailed on the job. Also, it is not enough for a newly recruited teacher to know the intensive information, knowledge, pros and cons of the profession. A secondary level teacher informant shared his ideas, "....I knew from media that I am selected for secondary school math teacher. Then I did contact to the DEDCU office and they suggested that office will inform me when the MoEST sends list of success candidates and allows posting. Finally, DEDCU invited to contact in office and to receive appointment letter for the recommended school. I went there. The head of DEDCU and school supervisor spent about one hour with me and they explained about the role and responsibilities. I came back to home with my appointment letter and the next day I went to meet with head teacher of the recommended school. He said to come another 
day in the school. I followed the day and went the school. He spent about 20 minutes with me and introduced with four teachers then he said to join the school from coming Sunday, the day I visited was Thursday. (KII, secondary school teacher)"

Similar way, another teacher respondent shared that civil service holders attend 45 days job induction program at the central level. They have an opportunity to understand the profession, organization and process of inclusion and handle. But teachers are not recognized and ignored by the system and authority. They are focused on how to pass the exam and then how to handle the class. There are no opportunities of learning about the profession, organization and future possibilities so that teachers are not enough encouraged and motivated.

The above sharing reflect the field reality about job induction where teachers and other civil service holders have different treatment. In gist, job induction is not in place, it is important for motivation and empowerment. It is better to address as a part of career development by the government.

\section{EXECUTION PROBLEMS WITH THE HIGHLY PRIORITIZED PROFESSIONAL DEVELOPMENT OF TEACHERS}

The first teacher education program (Aadhar Shikshya Talim, 1948), first National Education Planning Commission Report, (1955) and so on commission reports have put the first priority on teacher training program. Similarly, Education rule and regulation (2003) has defined on chapter 13 that there is a separate wing (National Center for Educational Development) for the professional development of teachers. Also, the development partners like; UNICEF, UNESCO, Plan international, Save the Children, and many other I/NGOs are focusing on different types of training programshttp://swc.org.np/ingos-detail-informations/. Beside these INGOs, NGOs and CBOs are also running short term and not accredited training courses for the community school teachers.

The flood of training programs are limited in the same area either teaching method or use of teaching materials. These are system base training program that any authority feels some lacking and designs the training program and run out. The training program run by the NGOs are more issue base but also system drive. They collect issues during their field visit and they develop the package and they run. It shows that the training are not demand base, not need base, also not addressing the individual difficulties. Different organizations come with the different style of presentation but on the same ground of the subject matter. It is a kind of confusion for teachers that a single teacher cannot mix up the different styles and ideas and to prepare his/her own way or idea to present the students. So that teacher loss the way even they cannot develop their own way to enable the students.

A teacher respondent shared his experience,

“......different non-government organizations organize training in different time which mostly not accredited by the government even it was collaborated with the government. The training provided by the government and non-government organizations are similar and all focused on teaching methodology. There is only difference on the way of presentation and use of materials during the training period. None of the training has addressed the issues that teachers are facing in the school or in the classroom. So, teachers enjoy the training program but they follow the same way like previous in the classroom. There are very few things implemented like; stopping corporal punishment, creating teacher - student friendly environment in the classroom, clean classroom etc (KII, teacher)".

The above responses of informants show that teachers are receiving training but not able to implement in the classroom. It also create another issue that the limitation of professional development in teacher training on teaching learning methodology only. There are other components missing like; motivation sessions, exposure visits, individual backstopping, resourcing, result base promotions etc. One report claims that classroom are not improved, teaching learning in the classroom is not interactive and student centered and there is not much different either the teacher is trained or not (MoEST, 2018). There are only individual differences reflected in the classroom teaching learning of teachers (ibid).

Informants also shared that there are some changes after receiving the training even the student's average achievement is not increased in a remarkable level. Classroom teaching learning is being more friendly and interactive to ensure the achievement. Also, there are other factors affecting student's motivation and learning achievement. They added that students' access to information technology, freedom at home, reduced control of teacher, liberal promotion are major challenges to grow students in a focused way.

\section{DISCUSSIONS AND IMPLICATIONS}

Research came to following discussion and implication of the findings so that the further researchers and the academic community may benefit with the results.

\section{Discussions}

There are different experiences and perspectives about job induction in this research also. Government officials, teachers and other stakeholders have not the same reflection about it. The findings clarify that the job induction is a missing miracle even the voice are divided because the government policy documents and the teacher stakeholders are in same line that there is no provision of job induction and not in practice also.

\section{Job induction is a missing fundamental in teaching profession}

The importance of job induction is unlimited because the entire job starts from the day. Research suggested that there are two important parts of job induction where new cohort of teachers and challenges of new authority is the first part. Similarly, enabling the ideas of each teacher so that they can exercise their habits properly over the students (Stanfield and Cremin 2013). Another research suggested that there are three most important stages for newly recruited teachers where they need additional support. They added that first week of appointment is most important for receiving necessary information, first six months of recruitment for developing competences, and the three months before of the first year for stability, sustainability and certainty (Sharplin, O’Neill et al. 2011). 
These evidences proof that teachers have not enough ideas in the beginning and they need more supports. In this sense, job induction can play an important role to explore their ideas, to be familiar with the professional and institutional profile, to way out new teachers roadmap for few months and finally to motivate and to encourage them. The good start up helps new teachers to perform better and to retain for long time in the schools.

\section{Unachieved results of teacher training program}

The above result findings concluded that there is not meaningful results of investment in teacher training program. Only the basic things are improved which are environmental and these are not because of training program specially. It means, the investment in training is not seen in the classroom and in the student's achievements. Pokhrel and Behera claims that Teacher's Professional Development (TPD) program in Nepal is not being success because of gaps between the TPD program and the teachers felt needs (Pokhrel and Behera 2016). They concluded in their report that teachers want resources, training plan in advance so that they can participate with preparation, TPD process is not set up as bottom - up, TPD sessions are more listening time rather than learning time, so that teachers want to involve in identifying new ideas during the TPD sessions and to set the plan for their schools (Pokhrel and Behera 2016).

This is an example of TPD but all other training program have similar issues that the real difficulties of teachers are not addressed.

One teacher informant added,

“....training provided by non-government organization and the government is similar. Non-government training look effective until they work in the school and they monitor. After that the classroom situation back to normal like previous. So, I am also surprised why the training is not implemented in the classroom. I think, it may require a different approach of training where teacher can play active role. (KII, teacher, Garuda municipality, Rautahat)".

Weir and Roberts conducted a research on training program and they concluded some serious issues in 30 years ago. Basically, these are influences in selection, biasness, methodological problems, and resource lacking (Weir and Roberts 1991). The research conducted in 2016 explains the similar issues with the research conducted in 1991. Since, there are some ongoing issues on teacher training program. Basically, the top - down approach of training model, methodology of training delivery and teacher resourcing are main problems.

\section{Implications}

This research helps to the government authority to apply job induction component as a key turning point in teaching profession for newly recruited teachers. Also, take ideas from research findings and to upgrade their training manuals towards more participatory and practicable. They can focus on improving classroom teaching learning and securing students' results when they are planning the teacher training program.

\section{REFERENCES}

[1] Acharya, U. D. (2006). Constitutionalism and Democracy in Nepal: what went wrong? SCIENZE SOCIALI: 177.

[2] Faubert, V. (2009). School evaluation: Current practices in OECD countries and a literature review.

[3] Hox, J. J. and H. R. Boeije (2005). Data collection, primary versus secondary.

[4] MoEST. (2017). The schools sector development plan: Teacher rationalization and redeployment plan. Kathamndu, Nepal: Author

[5] NCED. (2017). Shaichchhik suchana. Sanothimi, Bhaktapur, Nepal: Author

[6] Panta, B. B., Khanal, P., Luitel, B., Phyak, P. B. and et al. (2018). A study on identifying ways for managing school level teachers in federal system. Sanothimi, Bhaktapur, Nepal: DoE

[7] Parajuli, T., Thapa, D. and Shams F. (2013). Teacher management and development in Nepal. Kathmandu, Nepal: ADB

[8] Patton, M. Q. (1990). Qualitative evaluation and research methods. India: SAGE Publications, inc.

[9] Pokhrel, T. R. and S. K. Behera (2016). Expectations of teachers from teachers professional development program in Nepal. American Journal of Educational Research 4(2): 190-194.

[10] Sharma, G. N. (1990). The impact of education during the Rana period in Nepal. HIMALAYA, the Journal of the Association for Nepal and Himalayan Studies 10(2): 6.

[11] Sharplin, E., et al. (2011). Coping strategies for adaptation to new teacher appointments: Intervention for retention. Teaching and Teacher Education 27(1): 136-146.

[12] Soh, K. (2014). Finland and Singapore in PISA 2009: similarities and differences in achievements and school management. Compare: A Journal of Comparative and International Education 44(3): 455-471.

[13] Stanfield, J. and H. Cremin (2013). Importing control in Initial Teacher Training: theorizing the construction of specific habitus in recent proposals for induction into teaching. Journal of Education Policy 28(1): 21-37.

[14] Tamang, S. (2000). Legalizing state patriarchy in Nepal. Studies in Nepali History and Society 5(1): 127-156.

[15] Weir, C. and J. Roberts (1991). Evaluating a Teacher Training Project in Difficult Circumstances.

\section{AUTHORS}

First Author - Min Bdr. Shahi, PhD scholar, Tribhuvan University, Nepal, Contact at: smin1976@gmail.com 